\title{
Describing the Epidemiology of Foodborne Outbreaks in New South Wales from 2000 to 2017
}

\author{
Neil Franklin, ${ }^{1-3}$ Kirsty Hope, ${ }^{2}$ Keira Glasgow, ${ }^{2}$ and Kathryn Glass ${ }^{1}$
}

\begin{abstract}
Foodborne disease causes an estimated 4.1 million cases of illness in Australia each year and is responsible for causing many significant common source outbreaks. We analyzed 18 years of foodborne outbreak data collected in New South Wales (NSW), and classified the likely pathogen type responsible for outbreaks of unknown etiology, to track broad trends over time. A total of 869 outbreaks were reported in NSW from 2000 to 2017. The majority (53\%) of outbreaks did not have a pathogen identified and underwent pathogen type categorization based on the epidemiology of the outbreak. The proportion of outbreaks due to toxin producing bacteria decreased over time, whereas the proportion of outbreaks due to other bacterial pathogens increased. The proportion of outbreaks due to viral gastroenteritis pathogens had no overall changing trend over time. Bacterial outbreaks had significantly more identified cases and had more hospitalizations than other pathogen type causes. Other features associated with high case numbers, hospitalizations, and deaths in foodborne outbreaks included being due to food contaminated in primary production, involving consumption of raw products, and having evidence of poor sanitation in the food preparation areas. Eggs were the most commonly determined pathogen food source, occurring in $12 \%$ of outbreaks; however, most outbreak investigations (77\%) did not have a pathogen food source identified. This analysis demonstrates a changing landscape of foodborne outbreaks over time. Increases in outbreaks due to bacterial and viral pathogens coincide with increases in sporadic notifications of the same pathogens, whereas decreases in toxin caused outbreaks followed the introduction of mandatory food safety training in retail food businesses. Recognizing issues in food production and implementing improvements that reduce the number of pathogens in food will be key to reducing the incidence of foodborne outbreaks.
\end{abstract}

Keywords: disease outbreaks, foodborne infections, surveillance, Australia

\section{Introduction}

$\mathbf{F}$ OODBORNE ILLNESS CAUSES a considerable burden in Australia; estimates suggest that there are $\sim 4.1$ million cases of foodborne disease per year, with 30,840 hospitalizations and 76 deaths (Kirk et al., 2014), costing 1.2 billion dollars annually (Abelson et al., 2006). Foodborne illness outbreaks are complex investigations and there are many challenges in determining the etiology of an outbreak. As a result, only a small percentage of outbreaks identify a pathogen. Corrective public health action often requires identification of the pathogen, so these data gaps may limit our ability to prevent future outbreaks.

Systematic surveillance of foodborne diseases in Australia began in 2000 with the introduction of OzFoodNet, a col- laborative national network for the surveillance of enteric disease (OzFoodNet, 2000). Reports of several individual foodborne outbreaks have been published in the state of New South Wales (NSW) (Yohannes et al., 2002; Telfer et al., 2004; Pillsbury et al., 2013; Fitzgerald et al., 2014; Yapa et al., 2016; Thompson et al., 2017), but there has been no long-term analysis of foodborne outbreaks. Long-term surveillance can identify trends in foodborne outbreak risk factors, which can be used to inform food safety policy and advice.

The aims of this article are to provide an overview of foodborne illness outbreaks in NSW between 2000 and 2017 and to characterize changes over time. By classifying outbreaks by pathogen type, we track the cause of most outbreaks and identify the features of the most serious outbreaks.

\footnotetext{
${ }^{1}$ National Centre for Epidemiology and Population Health, Research School of Population Health, The Australian National University, Canberra, Australia.

${ }^{2}$ Communicable Diseases Branch, Health Protection NSW, NSW Ministry of Health, Sydney, Australia.

${ }^{3}$ Ozfoodnet, Department of Health, Canberra, Australia.
} 


\section{Methods}

The NSW OzFoodNet Outbreak Database captures standardized foodborne outbreak information for all outbreaks notified to NSW Health since 2000. A questionnaire is used that covers the outbreak setting, outbreak extent, mode of transmission, causative organism, results of epidemiological and environmental investigations, and the underlying causes of the outbreak. Data fields are not mandatory for reporting, so missing data are common for some variables. For this analysis, all outbreaks suspected to be foodborne between 2000 and 2017 were evaluated. All records were reviewed to ensure they met the foodborne outbreak case definition. Records that did not meet this definition were excluded. Definitions used in this database can be found in Supplementary Table S1.

The pathogen food source of the outbreak was also examined. Only outbreaks that had evidence of the contaminated food commodity were reported in the analysis. Outbreaks with compound ingredient meals without further critical determination of the contaminated food commodity were reported as pathogen food source unknown.

Outbreaks were further classified as either etiologyconfirmed (pathogen identified during the outbreak in cases or in the food investigation) or etiology-unconfirmed (pathogen not identified). Etiology-unconfirmed outbreaks were subsequently reviewed and assigned a likely pathogen type. The categorization was primarily based on meeting the known incubation period, symptom duration, and symptom profile of known foodborne outbreak pathogens (detailed in Table 1). If any of these fields were incomplete, a judgment on the pathogen type may still have been made based on the available information. All other collected information on file such as the foods consumed, environmental factors, and the notes and impressions made by outbreak investigators as well as the professional judgment of the authors was considered in assigning a pathogen cause. Outbreaks that did not have enough information or did not have enough differentiating information remained classified as unknown.

The new pathogen categories were as follows: bacterial toxin outbreak (henceforth referred to as "toxin outbreak"), bacterial pathogen outbreak ("bacterial outbreak"), viral gastroenteritis pathogen outbreak ("viral outbreak"), or unknown. These categories were chosen because the pathogen reservoir, symptoms, and process failures that can result in an outbreak of these pathogens are similar for each pathogen within each category (Table 1 ).

Foodborne outbreaks of the pathogens Listeria monocytogenes, hepatitis $\mathrm{A}$, and hepatitis $\mathrm{E}$ and fish poisoning outbreaks were not classified as they are qualitatively different outbreaks that are identified either by clinical identification of the pathogen or specific clinical symptoms, so are recognized as those illnesses before a foodborne outbreak being identified.

Data analysis was carried out using Stata 13.1 (StataCorp, 2013). The change in relative proportions over time was described using the chi-squared test for trend. Comparisons between outbreak characteristics (pathogen group, settings of outbreaks, and root causes) on outbreak severity measures (size of outbreak, the number hospitalized, and the number of deaths) were made using one-way or two-way analysis of variance with Bonferroni post-test.

\section{Results}

Between 2000 and 2017, 869 foodborne outbreaks were investigated in NSW. The number of outbreaks was variable over time with lowest counts in 2000, 2003, and 2017 (23, 37, and 37, respectively) and highest counts in 2012 and 2016 (64 and 70, respectively), with a median of 52 outbreaks a year (Fig. 1).

A total of 11,902 people were affected (range per outbreak: 2-391, median 6, mean 13.7), 1028 were hospitalized (range per outbreak: $0-136$, median 0 , mean 1.2), and 22 people died (range per outbreak: 0-7, median 0, mean 0.03). There were $408(47.0 \%)$ etiology-confirmed outbreaks. Salmonella was the most commonly identified pathogen $(n=267)$ and was responsible for the largest number of people affected $(n=4905)$, hospitalizations $(n=765)$, and deaths $(n=9)$. However, the highest mean number of people affected per outbreak was in norovirus outbreaks $(n=30.4$ people). The proportion of the total number of people affected, hospitalizations, and death rates was highest in Listeria outbreaks ( $100 \%$ and $14.3 \%$, respectively) (Table 2 ). Fish poisoning, hepatitis A, hepatitis E, and Listeria outbreaks accounted for $4.4 \%$ (38/869) of outbreaks. The remaining 369 etiologyconfirmed and 462 etiology-unconfirmed outbreaks underwent classification as "bacterial outbreaks," "toxin outbreaks,", or "viral outbreaks" (Table 3).

The proportion of bacterial outbreaks significantly increased over the 17-year period, being the least common before 2009 and then the most common after 2009 (minimum $8.7 \%$ in 2000 , maximum $64.3 \%$ in 2014 , average $34.9 \%$, $p<0.001$ for trend). The proportion of viral outbreaks did not vary significantly over time (minimum of $7.1 \%$ in 2014, maximum of $47.1 \%$ in 2016 , average $26.9 \%, p=0.14$ for trend). Toxin outbreaks were the most common until 2009, when these significantly decreased to be the least common (minimum of $10.0 \%$ in 2016, maximum of $49.0 \%$ in 2008 , average $26.8 \%, p<0.001$ for trend) (Fig. 2D).

\section{Outbreak severity}

The number of cases per outbreak showed no trend over time for any pathogen cause group. Overall, the mean number of people affected in an outbreak was 13.7 cases (yearly mean range 9.9 in 2015 and 24.2 in 2016). The mean number of people affected per outbreak was significantly higher in bacterial outbreaks (16.5 people per outbreak, $p=0.002)$ and viral outbreaks (17.4 people per outbreak, $p=0.001)$ than in toxin outbreaks (8.7 people per outbreak). The mean number of people hospitalized per outbreak was significantly higher in bacterial outbreaks (2.5 people per outbreak, $p<0.001)$ than in viral outbreaks ( 0.3 people per outbreak) and in toxin outbreaks (0.2 people per outbreak). The mean number of people who died per outbreak was largest in toxin outbreaks (0.04 people per outbreak) but was not statistically significantly different to bacterial outbreaks $(0.03$ people per outbreak) or viral outbreaks (0.004 people per outbreak) (Fig. 3A).

\section{Etiology-confirmed versus etiology-unconfirmed}

Outbreaks that were etiology-confirmed were compared with those that were assigned pathogens based on the outbreak epidemiology. Etiology-unconfirmed bacterial outbreaks had 


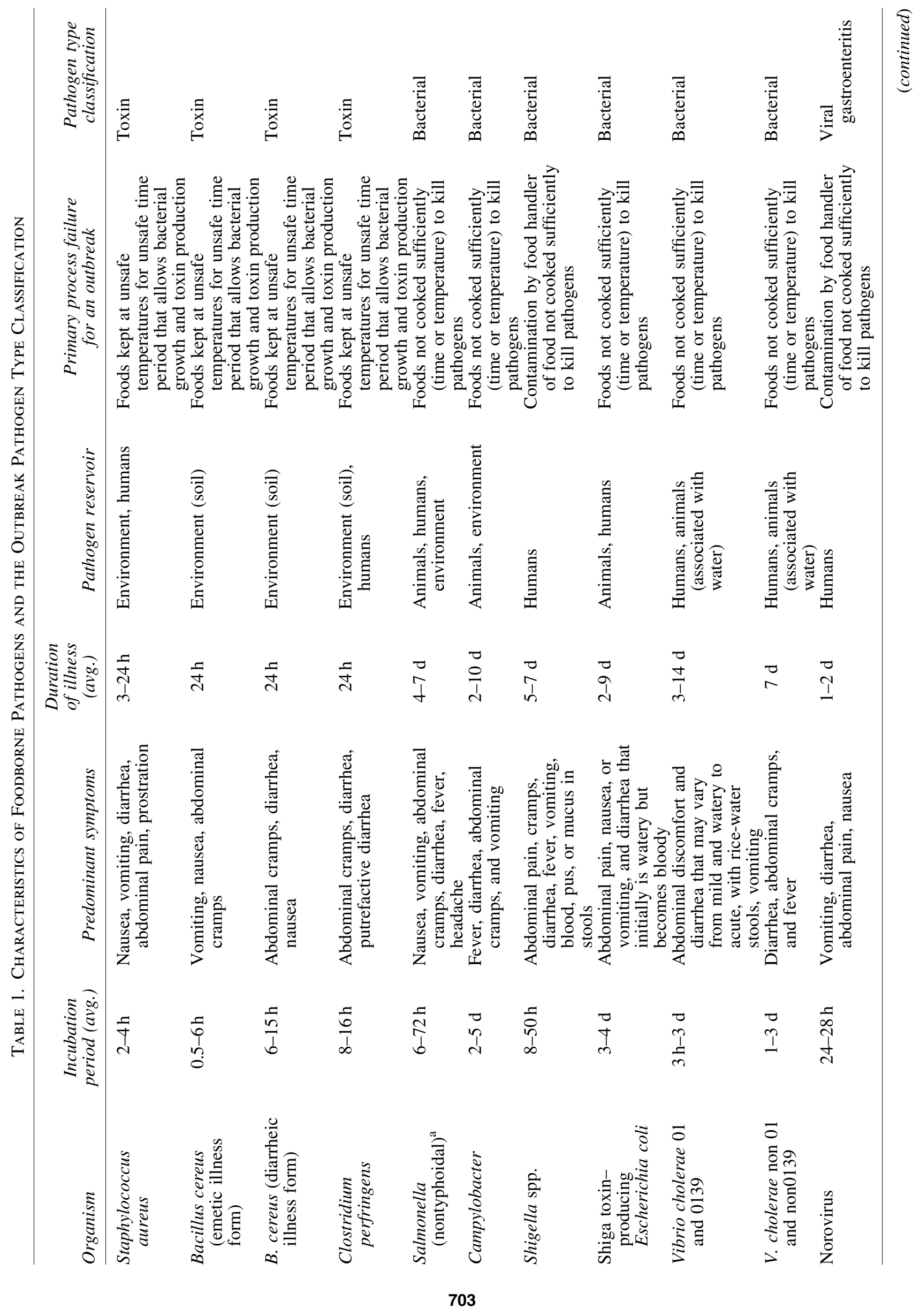




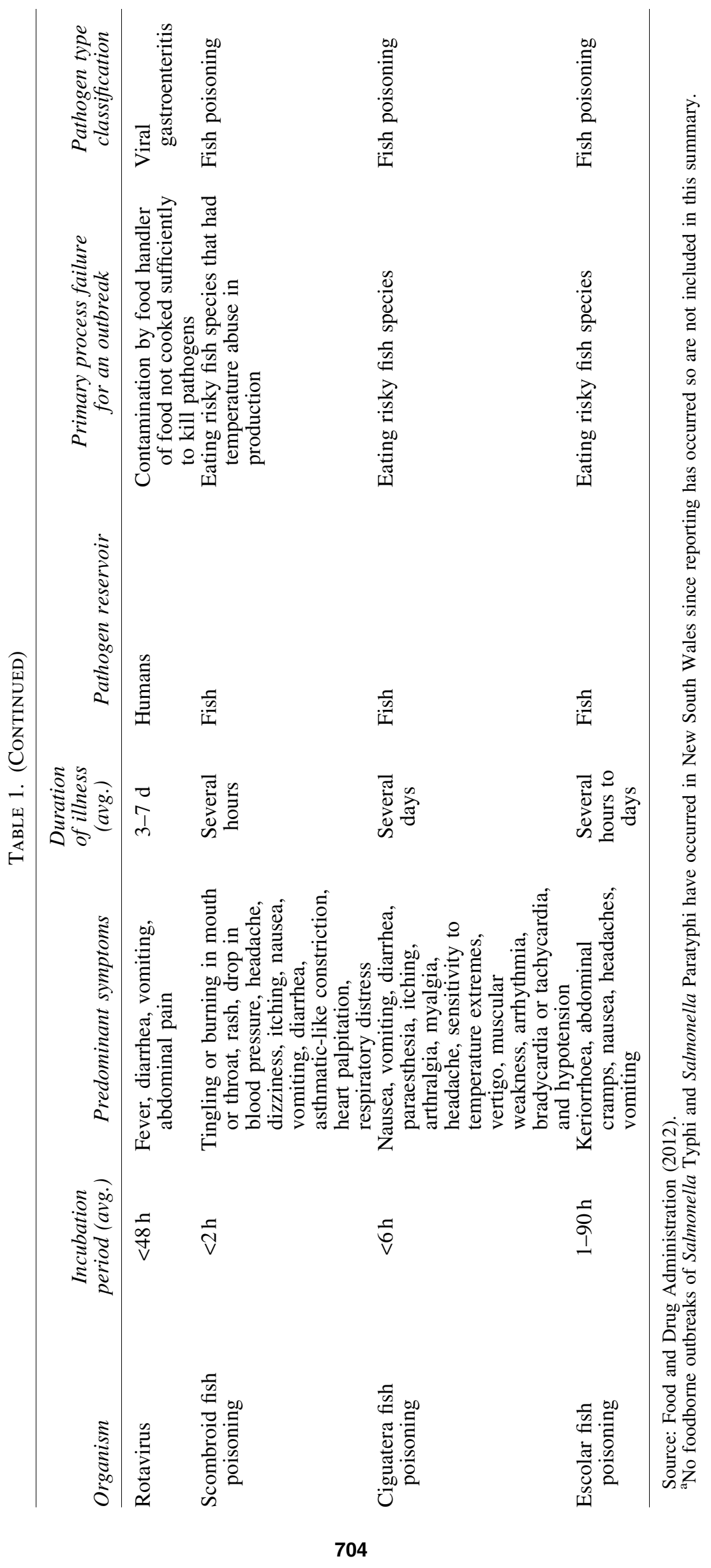




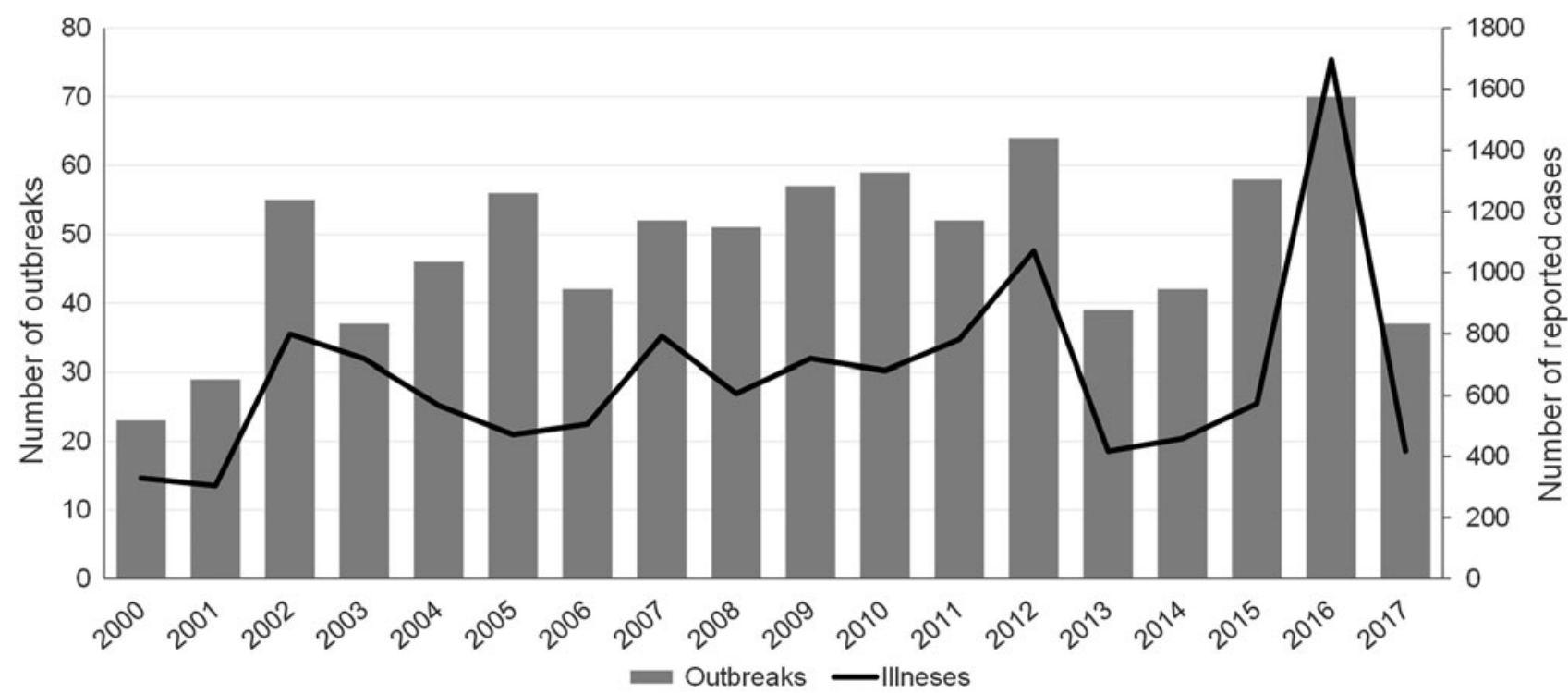

FIG. 1. Number of foodborne outbreaks and reported people affected per year in New South Wales (NSW), from 2000 to 2017.

similar incubation periods to etiology-confirmed bacterial outbreaks. However etiology-unconfirmed toxin and viral outbreaks had significantly shorter incubation periods than etiology-confirmed toxin and viral outbreaks $(7.9 \mathrm{~h}$ vs. $11.0 \mathrm{~h}, p=0.007$ and $25.3 \mathrm{~h}$ vs. $29.2 \mathrm{~h}, p=0.047)$. Etiologyunconfirmed outbreaks had similar symptom durations, except in bacterial outbreaks where symptom duration of etiology-unconfirmed outbreaks was significantly shorter than in etiology-confirmed outbreaks ( $3 \mathrm{~d}$ vs. $6.4 \mathrm{~d}, p<0.0001$ ). Etiology-confirmed outbreaks had higher average case numbers per outbreak, significantly so in toxin outbreaks (27.0 vs. $6.0, p<0.0001)$ and in viral outbreaks (30.0 vs. $14.6, p<0.0001)$.
Hospitalization rates were similar between etiology-confirmed and etiology-unconfirmed outbreaks except in bacterial outbreaks with etiology-confirmed outbreaks being significantly higher $(19.6 \%$ vs. $2.8 \%, p=0.004)$ (Table 2$)$.

\section{Outbreak settings}

Restaurants were the most common setting of outbreaks $(54.1 \%$; $470 / 869)$, followed by takeaway venues $(18.1 \%$; $157 / 869)$ and private kitchens $(9.3 \% ; 81 / 869)$. Outbreaks due to food consumed as unprocessed primary produce had the highest mean number of people ill (79.4 cases, $p<0.001)$ and

Table 2. Descriptive Summary of Foodborne Outbreaks by Confirmed Pathogens

\begin{tabular}{|c|c|c|c|c|c|c|c|}
\hline Pathogen identified & $\begin{array}{c}\text { No. of } \\
\text { outbreaks }\end{array}$ & $\begin{array}{c}\text { Total } \\
\text { ill }\end{array}$ & $\begin{array}{l}\text { Average } \\
\text { per } \\
\text { outbreak }\end{array}$ & $\begin{array}{c}\text { Total } \\
\text { hospitalized }\end{array}$ & $\begin{array}{l}\text { Hospitalization } \\
\text { rate }(\%)\end{array}$ & $\begin{array}{l}\text { Total } \\
\text { died }\end{array}$ & $\begin{array}{l}\text { Death } \\
\text { rate } \\
(\%)\end{array}$ \\
\hline Salmonella spp., nontyphoidal & 267 & 4905 & 18.4 & 765 & 15.6 & 9 & 0.2 \\
\hline Campylobacter spp. & 24 & 140 & 5.8 & 12 & 8.6 & 0 & 0.0 \\
\hline Listeria monocytogenes & 5 & 21 & 4.2 & 21 & 100.0 & 3 & 14.3 \\
\hline Shigella spp. & 3 & 19 & 6.3 & 1 & 5.3 & 0 & 0.0 \\
\hline $\begin{array}{l}\text { Shiga toxin-producing } \\
\text { Escherichia coli }\end{array}$ & 1 & 6 & 6.0 & 5 & 83.3 & 0 & 0.0 \\
\hline Vibrio spp. & 3 & 8 & 2.7 & 3 & 37.5 & 0 & 0.0 \\
\hline Clostridium perfringens & 23 & 694 & 30.2 & 6 & 0.9 & 9 & 1.3 \\
\hline Bacillus cereus & 2 & 46 & 23.0 & 0 & 0.0 & 0 & 0.0 \\
\hline Staphylococcus aureus & 4 & 44 & 11.0 & 11 & 25.0 & 0 & 0.0 \\
\hline Hepatitis A & 4 & 36 & 9.0 & 4 & 11.1 & 0 & 0.0 \\
\hline Hepatitis E & 1 & 17 & 17.0 & 6 & 35.3 & 0 & 0.0 \\
\hline Norovirus & 42 & 1277 & 30.4 & 28 & 2.2 & 1 & 0.1 \\
\hline Rotavirus & 1 & 14 & 14.0 & 0.0 & 0 & 0.0 & 0.0 \\
\hline Scombroid poisoning & 18 & 61 & 3.4 & 39.3 & 0 & 0.0 & 0.0 \\
\hline Ciguatera poisoning & 9 & 46 & 5.1 & 26 & 56.5 & 0 & 0.0 \\
\hline Escolar fish poisoning & 1 & 20 & 20 & 0.0 & 0 & 0.0 & 0.0 \\
\hline No pathogen identified & 461 & 4548 & 9.9 & 113 & 2.5 & 0 & 0.0 \\
\hline Total & 869 & 11,902 & 13.7 & 1028 & 8.6 & 22 & 0.2 \\
\hline
\end{tabular}


Table 3. Comparison of Etiology-Confirmed and Etiology-UnConfirmed Outbreaks by Pathogen Type Classification

\begin{tabular}{|c|c|c|c|c|c|c|c|c|c|}
\hline $\begin{array}{l}\text { Pathogen type } \\
\text { classification }\end{array}$ & $\begin{array}{l}\text { No. of } \\
\text { outbreaks } \\
\text { (\%) }\end{array}$ & $\begin{array}{l}\text { Incubation } \\
\text { (days or } \\
\text { hours) }\end{array}$ & $\begin{array}{c}\mathrm{p} \text {-value } \\
\text { for } \\
\mathrm{t} \text {-test }\end{array}$ & $\begin{array}{c}\text { Duration } \\
\text { (days or } \\
\text { hours) }\end{array}$ & $\begin{array}{c}\mathrm{p} \text {-value } \\
\text { for } \\
\mathrm{t} \text {-test }\end{array}$ & $\begin{array}{c}\text { Average } \\
\text { cases } \\
\text { per } \\
\text { outbreak }\end{array}$ & $\begin{array}{c}\mathrm{p} \text {-value } \\
\text { for } \\
\mathrm{t} \text {-test }\end{array}$ & $\begin{array}{l}\text { Hospitalization } \\
\text { rate }\end{array}$ & $\begin{array}{c}\mathrm{p} \text {-value } \\
\text { for } \\
\mathrm{t}-\text { test }\end{array}$ \\
\hline Bacterial outbreaks & $315(36.3)$ & $1.3 \mathrm{~d}$ & - & $6.2 \mathrm{~d}$ & - & 16.5 & - & 18.6 & - \\
\hline $\begin{array}{l}\text { Etiology- } \\
\text { confirmed }\end{array}$ & 297 (94.3) & $1.4 \mathrm{~d}$ & & $6.4 \mathrm{~d}$ & & 17.1 & & 19.6 & \\
\hline $\begin{array}{l}\text { Etiology- } \\
\text { unconfirmed }\end{array}$ & $18(6.7)$ & $1.0 \mathrm{~d}$ & 0.114 & $3.0 \mathrm{~d}$ & $<0.001$ & 7.2 & 0.247 & 2.8 & 0.004 \\
\hline Toxin outbreaks & $228(26.2)$ & $8.3 \mathrm{~h}$ & - & $22.9 \mathrm{~h}$ & - & 8.7 & - & 3.5 & - \\
\hline $\begin{array}{l}\text { Etiology- } \\
\text { confirmed }\end{array}$ & $29(12.7)$ & $11.0 \mathrm{~h}$ & & $27.2 \mathrm{~h}$ & & 27 & & 4 & \\
\hline $\begin{array}{l}\text { Etiology- } \\
\text { unconfirmed }\end{array}$ & 199 (27.3) & $7.9 \mathrm{~h}$ & 0.007 & $22.4 \mathrm{~h}$ & 0.145 & 6.0 & $<0.001$ & 3.5 & 0.872 \\
\hline Viral outbreaks & $237(27.3)$ & $26.0 \mathrm{~h}$ & - & $1.8 \mathrm{~d}$ & - & 17.4 & - & 2.1 & \\
\hline & 43 (18.9) & $29.2 \mathrm{~h}$ & & $1.9 \mathrm{~d}$ & & 30 & & 2.1 & \\
\hline $\begin{array}{l}\text { Etiology- } \\
\text { unconfirmed }\end{array}$ & $194(81.1)$ & $25.3 \mathrm{~h}$ & 0.047 & $1.7 \mathrm{~d}$ & 0.155 & 14.6 & $<0.001$ & 2.1 & 0.955 \\
\hline Unknown & $51(5.9)$ & $14.8 \mathrm{~h}$ & - & $2.1 \mathrm{~d}$ & - & 7.6 & - & 4.9 & - \\
\hline
\end{tabular}

Values in bold indicate significant association $(p<0.05)$.

highest average number of people hospitalized per outbreak (5.9 people hospitalized, $p=0.376$ ). Outbreaks in institutional settings had higher average number of deaths per outbreak $(0.22$ deaths, $p<0.001)$ followed by outbreaks of commercially manufactured products $(0.21$ deaths per outbreak, $p<0.001$ ) than other settings (Fig. 3B).

\section{Pathogen food source}

A suspected contaminated dish was reported in $54.0 \%$ (496/869) of outbreaks and the contaminated food commodity was determined in $22.8 \%$ (198/869) of outbreaks. Bacterial outbreaks had a significantly higher proportion of outbreaks with a contaminated food commodity identified $(46.7 \%)$, compared with toxin outbreaks $(3.5 \%)$ and viral outbreaks $(3.0 \%)(p<0.001)$.

Eggs were the most common identified food commodity in $108 / 869$ (12.4\%) outbreaks. All but one of the egg outbreaks were etiology-confirmed Salmonella outbreaks, accounting for $40.1 \%$ of Salmonella outbreaks. Oysters were the only food associated with viral foodborne outbreaks and the fourth-most common food commodity overall (8/869 outbreaks, $1.0 \%$ ), predominantly (in 6 of 8 ) associated with etiology-confirmed norovirus. Within toxin outbreaks, most $(96.5 \%)$ had an unknown source of the pathogen (Table 4).

\section{Root causes}

The potential route of contamination of the food was recorded for $34.0 \%$ of outbreaks. From these outbreaks, the most common method of introduction of a pathogen into food was via contaminated raw produce $(41.6 \%)$ followed by contamination of food from the food preparation environment $(38.7 \%)$. There was no significant difference between the average number of cases in outbreaks by a contributing factor, although outbreaks due to contaminated raw produce had significantly higher numbers hospitalized (4.1 per outbreak, $p<0.001$ ) (Fig. 3C). The reason for pathogen survival in the food was reported in $26.5 \%$ of outbreaks, in which the most common cause was inadequate cooking temperature/time (49.1\%) followed by foods being left at unsafe temperatures $(48.3 \%)$. Although only reported in $17.4 \%$ of these outbreaks, outbreaks with evidence of failed sanitization (insufficient disinfectant saturation or inadequate cleaning practice) as the factor contributing to pathogen survival had significantly more people affected (average 41.7 people per outbreak, $p<0.001$ ), significantly more people hospitalized (average 6.9 people per outbreak, $p=0.002$ ), and significantly more deaths during the outbreak (average of 0.13 people per outbreak, $p<0.001$ ) than other pathogen survival causes (Fig. 3D).

\section{Discussion}

Since the year 2000, the number of foodborne outbreaks investigated in NSW has varied. By assigning pathogen causes to outbreaks we have been able to show that there has been a change in the predominant pathogen cause of foodborne outbreaks. Before 2009, toxin outbreaks were the most common type of outbreak investigated. Since then, bacterial outbreaks (primarily due to Salmonella) have become the most common cause of foodborne outbreaks and have shown the most serious illness outcomes. Reviews of outbreak data from other countries show low proportions of outbreaks due to bacterial toxins $[14.3 \%$ in the United Kingdom (Gormley et al., 2011) and 9.2\% in the United States (Gould et al., 2013)], although these proportions are presented in those articles without consideration of potential toxin outbreaks among the outbreaks of unknown etiology.

The observed decrease in toxin outbreaks from 2009 followed the introduction of the Food Safety Supervisor training 

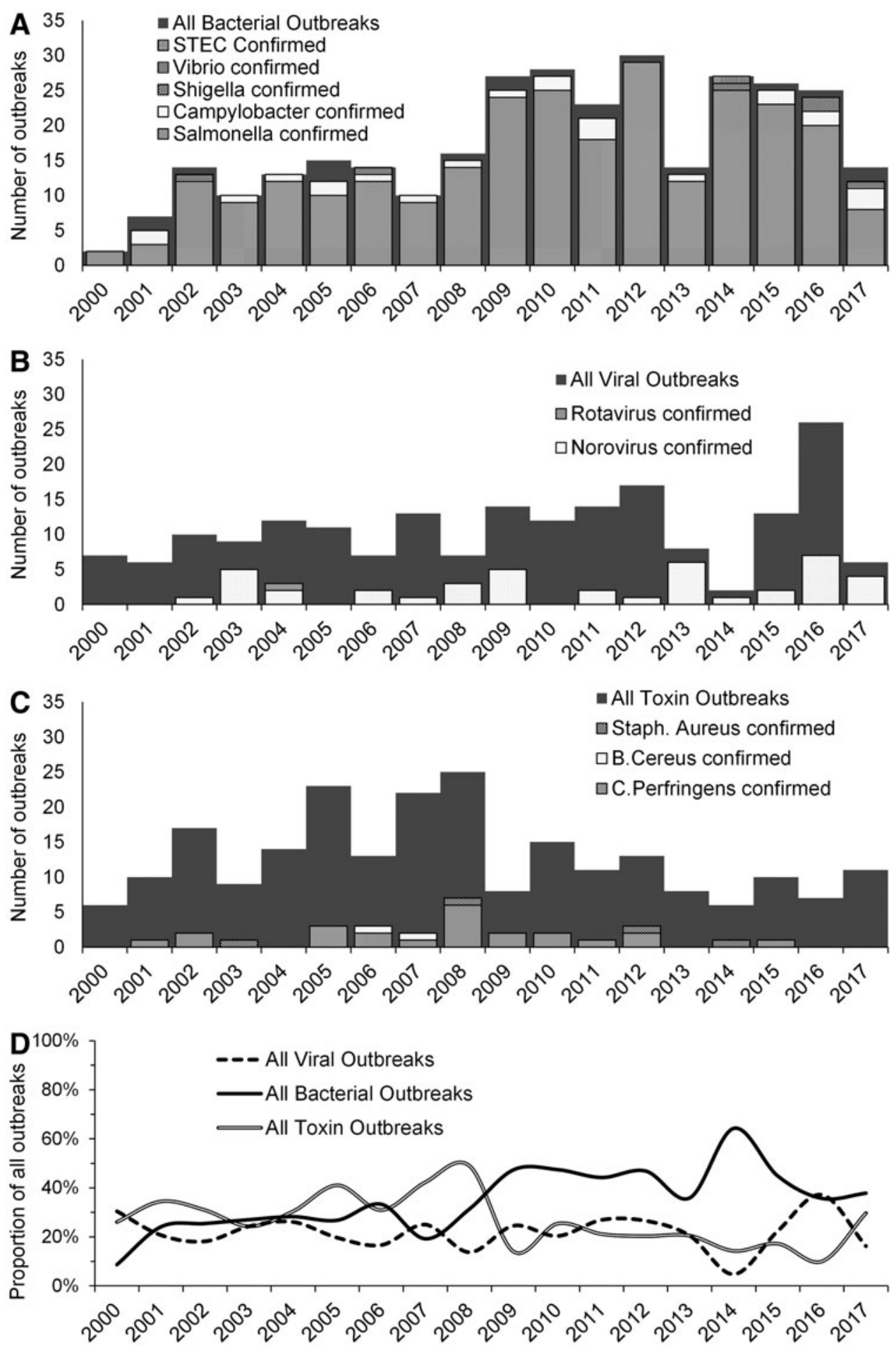

FIG. 2. Number of (A) bacterial outbreaks, (B) viral outbreaks, (C) toxin outbreaks, including numbers confirmed by pathogen, and (D) proportion of breakdown by pathogen type category per year in NSW, from 2000 to 2017.

program by the NSW Government food safety regulatory agency (NSW Food Authority, 2015). Mandatory training began in 2009 to ensure that food businesses in NSW had an employee who was appropriately trained in food safety. This training included sanitization and temperature control, which help prevent outbreaks caused by bacterial toxins, potentially explaining the reduction of toxin outbreaks. In contrast, the increase in bacterial outbreaks follows closely the rates for sporadic Salmonella notifications, which also peaked between 2009 and 2016 in NSW (NSW Ministry of Health, 2017). Although viral outbreaks showed no overall trend, more outbreaks were observed in years that also had higher amounts of community person-to-person spread of viral gastroenteritis, which peaked in institutional settings in 2009 


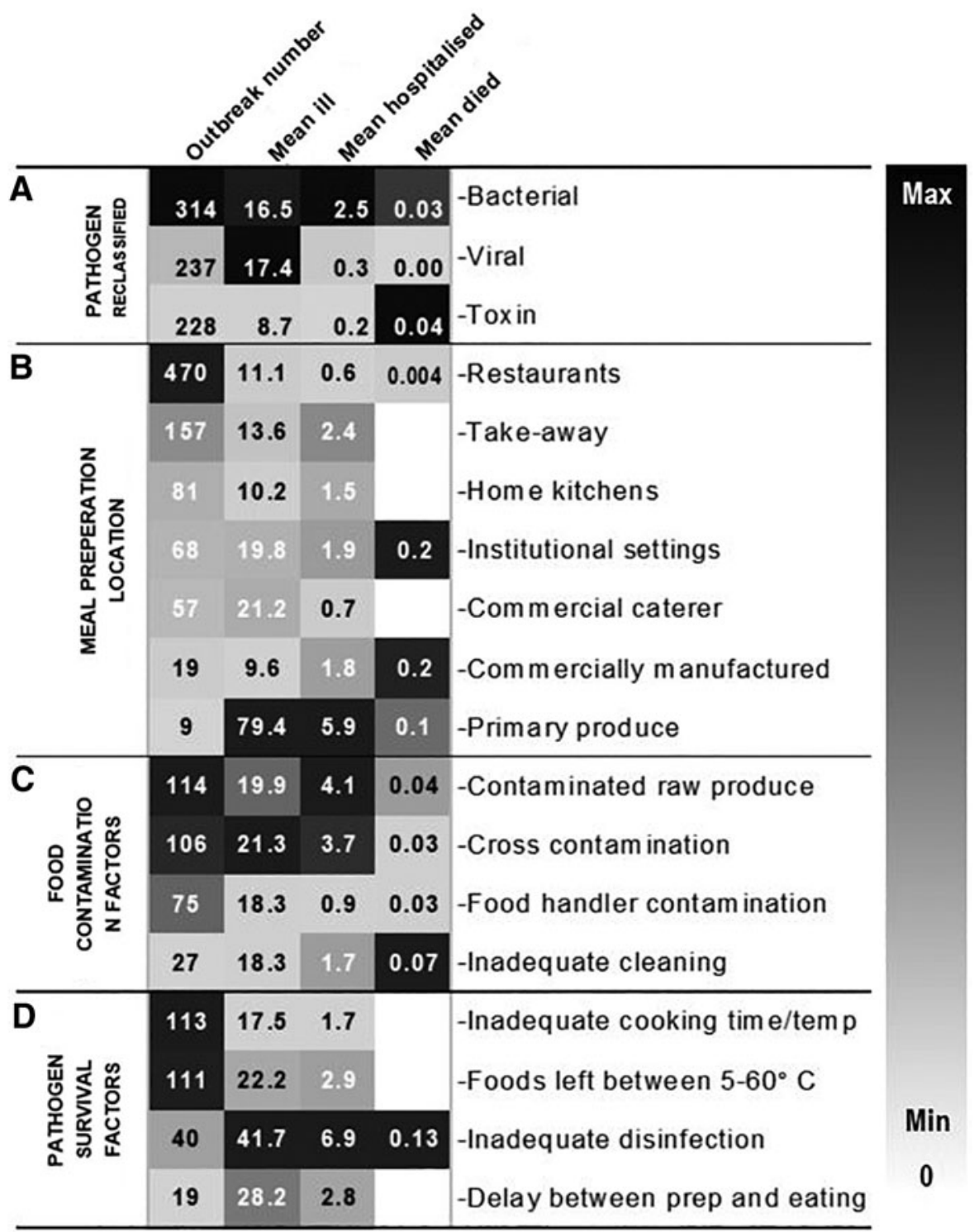

FIG. 3. Heat maps of severity measures; number of outbreaks, the mean number ill per outbreak, the mean number hospitalized per outbreak, and the mean number who died per outbreak by (A) reclassified pathogen type, (B) where the meal was prepared, (C) factors contributing to food contamination, and (D) factors contributing to pathogen survival.

(NSW Ministry of Health, 2009), 2012 (NSW Ministry of Health, 2012), and 2016 (NSW Ministry of Health, 2016), suggesting spillover from person-to-person outbreaks to person-to-food-to-person outbreaks.

A potential limitation to this analysis is that there may have been changes to investigation resources or techniques over the period of this analysis, which would have the potential to affect trends over time. However, as there was no change to the outbreak definition, reporting processes, the threshold for investigating an outbreak, or the data collection tools, we feel the number of outbreaks reported at any one time would not have been affected by the resources of the day. In addition, there were no improvements in investigation techniques that would have allowed for more efficient resolution of outbreak outcomes or time lines. Another limitation could be that the outbreaks summarized are predominantly from a passive surveillance system; outbreaks with lesser clinical symptoms and from non-notifiable pathogens (such as those caused by bacterial toxins and viral pathogens) may not reach the level of public health investigation, and thus be omitted from this database. Although this would not affect the trends seen in this analysis, it may bias the results toward outbreaks with more serious outcomes.

Misclassification of pathogen causes for etiologyunconfirmed outbreaks is a potential limitation of this study. A comparison of outbreaks with etiology confirmed and etiology unconfirmed showed that etiology-confirmed outbreaks had a longer incubation period, greater duration of symptoms, affected more people, and had more hospitalizations. These differences do not necessarily signify that the groups are incorrectly classified but may represent differences between mild and more serious outbreaks. Outbreaks with serious outcomes (more people, sick for more days, and more hospitalizations) have greater opportunity for the 
Table 4. Food Source of Pathogens IN FOODBORNE OUTBREAKS

\begin{tabular}{|c|c|c|c|}
\hline Pathogen & Food source & $\begin{array}{c}\text { No. of } \\
\text { outbreaks }\end{array}$ & $\begin{array}{c}\text { No. } \\
\text { ill }\end{array}$ \\
\hline \multirow{7}{*}{$\begin{array}{l}\text { Bacterial outbreaks } \\
\text { Campylobacter }\end{array}$} & & 315 & 5202 \\
\hline & & 23 & 135 \\
\hline & Chicken & 5 & 39 \\
\hline & $\begin{array}{l}\text { Liver- } \\
\text { chicken }\end{array}$ & 4 & 18 \\
\hline & Liver-duck & 1 & 17 \\
\hline & Liver-lamb & 1 & \\
\hline & Unknown & 12 & 59 \\
\hline \multirow[t]{13}{*}{ Salmonella } & & 267 & 4905 \\
\hline & Almonds & 1 & \\
\hline & Bagged lettuce & 1 & 24 \\
\hline & Bean sprouts & 1 & 100 \\
\hline & Chicken & 14 & 579 \\
\hline & Egg & 107 & 1980 \\
\hline & Ham & 1 & 16 \\
\hline & Liver_lamb & 1 & 43 \\
\hline & Peanuts & 1 & 2 \\
\hline & Pork & 2 & \\
\hline & Rockmelon & 2 & 182 \\
\hline & Tahini & 1 & 51 \\
\hline & Unknown & 135 & 1894 \\
\hline \multirow[t]{2}{*}{ Shigella } & & 3 & 19 \\
\hline & Unknown & 3 & 19 \\
\hline \multirow[t]{2}{*}{$\begin{array}{l}\text { Shiga toxin- } \\
\text { producing } \\
\text { Escherichia coli }\end{array}$} & & 1 & \\
\hline & Unknown & 1 & \\
\hline \multirow[t]{4}{*}{ Unknown } & & 18 & 129 \\
\hline & Chicken & 1 & \\
\hline & Egg & 1 & 3 \\
\hline & Unknown & 16 & 97 \\
\hline \multirow[t]{2}{*}{ Vibrio cholerae 01} & & 1 & \\
\hline & Fish & 1 & \\
\hline \multirow[t]{2}{*}{ Vibrio albensis } & & 1 & \\
\hline & Oysters & 1 & \\
\hline \multirow[t]{2}{*}{$\begin{array}{l}\text { Vibrio } \\
\quad \text { parahaemolyticus }\end{array}$} & & 1 & \\
\hline & Unknown & 1 & \\
\hline Toxin outbreaks & & 228 & 1986 \\
\hline \multirow[t]{2}{*}{ Bacillus cereus } & & 2 & 46 \\
\hline & Unknown & 2 & 46 \\
\hline \multirow[t]{4}{*}{$\begin{array}{l}\text { Clostridium } \\
\text { perfringens }\end{array}$} & & 23 & 694 \\
\hline & Gravy & 1 & 31 \\
\hline & Pork & 1 & 80 \\
\hline & Unknown & 21 & 583 \\
\hline \multirow[t]{2}{*}{$\begin{array}{l}\text { Staphylococcus } \\
\text { aureus }\end{array}$} & & 4 & 4 \\
\hline & Unknown & 4 & 44 \\
\hline \multirow[t]{7}{*}{ Unknown } & & 199 & 1202 \\
\hline & Gravy & 1 & 1 \\
\hline & Ham & 1 & \\
\hline & Juice & 1 & \\
\hline & Mussels & 2 & \\
\hline & Rice & 1 & \\
\hline & Unknown & 193 & 1172 \\
\hline
\end{tabular}

(continued)
TABLE 4. (CONTINUED)

\begin{tabular}{llrr}
\hline Pathogen & Food source & $\begin{array}{c}\text { No. of } \\
\text { outbreaks }\end{array}$ & $\begin{array}{r}\text { No. } \\
\text { ill }\end{array}$ \\
\hline Viral outbreaks & & 237 & 4126 \\
Norovirus & & 42 & 1277 \\
& Oysters & 6 & 57 \\
Rotavirus & Unknown & 36 & 1220 \\
& Unknown & 1 & 14 \\
Unknown & & 1 & 14 \\
& Oysters & 1 & 2835 \\
Fish poisoning & Unknown & 193 & 2831 \\
outbreaks & & 28 & 127 \\
Ciguatera poisoning & & 9 & 46 \\
Escolar fish & & 1 & 20 \\
poisoning & & 18 & 61 \\
Scombroid poisoning & & 5 & 21 \\
Listeria & & & \\
monocytogenes & & 1 & 2 \\
& Chicken & 1 & 3 \\
& Ham & 2 & 10 \\
& Soft cheese & 6 \\
Hepatitis A & Unknown & 4 & 36 \\
& & 2 & 19 \\
Hepatitis E & Frozen berries & 2 & 17 \\
Outbreaks of unknown & Unknown & 1 & 17 \\
pathogen & Liver-pork & 1 & 17 \\
& & 51 & 387 \\
& Chicken & 1 & 2 \\
& Liver & 1 & 9 \\
& Unknown & 49 & 376 \\
& & &
\end{tabular}

pathogen to be confirmed. Similarly, pathogens with longer symptom durations (bacterial pathogens) were more likely to be etiology confirmed than those with short symptom durations (bacterial toxin and viral pathogens). Epidemiologists will logically infer the pathogen classification during an outbreak investigation based on symptoms to help guide the investigation. However, this is the first time these assumptions have been used to track outbreak trends.

Features associated with the most serious foodborne outbreaks included the following: food contaminated in primary production, consumption of raw products, and preparation in food areas with evidence of poor sanitization. The pathogen group with the most serious outcomes was bacterial outbreaks, with higher numbers ill and hospitalized; this is consistent with these pathogens having more serious morbidity (Kirk et al., 2015) and highlights the importance of prioritizing public health resources to follow up these incidents. Toxin outbreaks had a higher mean number of deaths than other outbreaks, with all toxin outbreak deaths occurring in aged care institutional settings. This is consistent with previous studies that showed high mortality in toxin-mediated outbreaks in this vulnerable population (May et al., 2016).

Most (77.2\%) outbreaks in NSW did not have a food source of the pathogen found. The only pathogen food source 
that was determined with any regularity was eggs (12.4\% of outbreaks). Eggs are a well-known source of Salmonella outbreaks in Australia (Moffatt et al., 2016); heightened awareness about the risk of salmonellosis in eggs in NSW and raw-egg containing foods likely improved the ability of investigators to draw links to the food source in those outbreaks. Most outbreaks due to viral pathogens and bacterial toxin outbreaks did not have a food source identified. An indepth analysis of foods, dishes, and cooking methods used in foodborne outbreaks is underway to help understand what foods cause foodborne outbreaks. This will enable us to understand the process failures and recommend food safety and public health messaging to reduce incidence.

In response to increasing Salmonella notification rates, the NSW Food Authority introduced a 5-year strategy for reducing foodborne illnesses (NSW Government Food Authority, 2015) in 2015, which informed the development of the national strategy in 2018 (Food Regulation Secretariat, 2018). Both focus on action at all points along the food supply chain from the farm to the consumer. This analysis demonstrates that outbreak causes and serious outcomes can arise at each step along this pathway. A limitation to the application of this analysis and for the foodborne illness reduction strategies is the lack of data on sporadic cases of illness and the corresponding food safety lessons necessary to correct them. This information will be important to address the large number of foodborne illnesses that are not part of an outbreak.

\section{Conclusion}

Thanks to a long-standing database that used consistent collection methods over time, we were able to analyze longterm trends and found that the pathogen type cause of these outbreaks has changed over time. Public health and food safety agencies must therefore be able adapt to this changing epidemiology. To reduce the incidence of foodborne outbreaks, public health and food safety sectors must address pathogen increases as well as ensure that food safety breaches are found and corrected in food production and food delivery sectors.

\section{Acknowledgment}

We thank the NSW public health network that investigated these outbreaks in conjunction with the NSW Food Authority.

\section{Disclosure Statement}

No competing financial interests exist.

\section{Funding Information}

We thank the OzFoodNet Network, which is funded by the Australian Government Department of Health.

\section{Supplementary Material}

Supplementary Table S1

\section{References}

Abelson P, Potter Forbes M, Hall G. The annual cost of foodborne illness in Australia. Canberra: Australian Department of Health and Ageing, 2006.
Centre for Food Safety and Applied Nutrition (U.S.). Bad Bug Book, Foodbome Pathogenic Microorganisms and Natural Toxins. Second Edition. Washington, DC: U.S. Food and Drug Administration, Center for Food Safety and Applied Nutrition, 2012.

Fitzgerald TL, Merritt TD, Zammit A, McLeod C, Landinez LM, White PA, Munnoch SA, Durrheim DN. An outbreak of norovirus genogroup II associated with New South Wales oysters. Commun Dis Intell Q Rep 2014;38:E9-E15.

Food Regulation Secretariat. Australia's foodborne illness reduction strategy 2018-2021+. 2018. Available at: http:// foodregulation.gov.au/internet/frJpublishing.nsf/Contentiausfoodborne-iIlness-reduction-strategy-2018-2021-Jun-2018, accessed November 12, 2019.

Gormley FJ, Little CL, Rawal N, Gillespie IA, Lebaigue S, Adak GK. A 17-year review of foodborne outbreaks: Describing the continuing decline in England and Wales (19922008). Epidemiol Infect 2011;139:688-699.

Gould LH., Walsh KA, Vieira AR, Herman K, Williams IT, Hall AJ, Cole D; Centers for Disease and Prevention. Surveillance for foodborne disease outbreaks-United States, 1998-2008. MMWR Surveill Summ 2013;62:1-34.

Kirk M, Ford L, Glass K, Hall G. Foodborne illness, Australia, circa 2000 and circa 2010. Emerg Infect Dis 2014;20:18571864.

Kirk MD, Pires SM, Black RE, Caipo M, Crump JA, Devleesschauwer B, Döpfer D, Fazil A, Fischer-Walker CL, Hald T, Hall AJ, Keddy KH, Lake RJ, Lanata CF, Torgerson PR, Havelaar AH, Angulo FJ. World Health Organization estimates of the global and regional disease burden of 22 foodborne bacterial, protozoal, and viral diseases, 2010: A data synthesis. PLoS Med 2015;12:e1001921-e1001921.

May FJ, Polkinghorne BG, Fearnley EJ. Epidemiology of bacterial toxin-mediated foodborne gastroenteritis outbreaks in Australia, 2001 to 2013. Commun Dis Intell Q Rep 2016; 40:E460-e469.

Moffatt CR, Musto J, Pingault N, Miller M, Stafford R, Gregory J, Polkinghorne BG, Kirk MD. Salmonella Typhimurium and outbreaks of egg-associated disease in Australia, 2001 to 2011. Foodborne Pathog Dis 2016;13:379-385.

NSW Food Authority. Food Safety Supervisor Scheme Evaluation: Results Summary Report. 2015. Available at: http:// www.foodauthority.nsw.gov.auLDocuments/fss/fss_evaluation .pdf, accessed November 12, 2019.

NSW Government Food Authority. NSW Government Food Safety Strategy 2015-2021. 2015. Available at: http://www .foodauthority.nsw.gov.auLDocuments//corporate/Food_Safety_ Strategy.pdf, accessed November 12, 2019.

NSW Ministry of Health. NSW 2009 OzFoodnet Annual Report. 2009. Available at: https://www.health.nsw.gov.au/ Infectiousidiseases/Documents/NSW-ofn-annual-report-2009 .pdf, accessed June 30, 2019.

NSW Ministry of Health. NSW 2012 OzFoodnet Annual Report. 2012. Available at: https://www.health.nsw.gov.au/ Infectious/foodborne/Publications/NSW-ofn-annual-report2012.pdf, accessed June 30, 2019.

NSW Ministry of Health. NSW 2016 OzFoodnet Annual Report. 2016. Available at: www.health.nsw.gov.au/Infectious/ foodborne/Documents/NSW-ofn-annual-report-2016.pdf, accessed June 30, 2019.

NSW Ministry of Health. NSW 2017 OzFoodnet Annual Report. 2017. Available at: www.health.nsw.gov.au/Infectious/ foodborne/Documents/NSW-ofn-annual-report-2017.pdf, accessed June 30, 2019. 
OzFoodNet. 2000. Available at: http://health.gov.au/internet/ main/publishing.nsf/Content/cdna-ozfoodnet.htm, accessed June 30, 2017.

Pillsbury A, Chiew M, Bates J, Sheppeard V. An outbreak of staphylococcal food poisoning in a commercially catered buffet. Commun Dis Intell Q Rep 2013;37:E144E148.

StataCorp. Stata Statistical Software: Release 13. College Station, TX: StataCorp LP, 2013.

Telfer B, Capon A, Kolbe T, Hamilton I, Burns T, Doyle B, Musto J, McAnulty J. A large outbreak of norovirus gastroenteritis linked to a catering company, New South Wales, October 2003. N S W Public Health Bull 2004;15: 168-171.

Thompson CK, Wang Q, Bag SK, Franklin N, Shadbolt CT, Howard P, Fearnley EJ, Quinn HE, Sintchenko V, Hope KG. Epidemiology and whole genome sequencing of an ongoing point-source Salmonella Agona outbreak associated with sushi consumption in western Sydney, Australia 2015. Epidemiol Infect 2017;145:2062-2071.
Yapa CM, Furlong C, Rosewell A, Ward KA, Adamson S, Shadbolt C, Kok J, Tracy SL, Bowden S, Smedley EJ, Ferson MJ, Sheppeard V, McAnulty JM. First reported outbreak of locally acquired hepatitis E virus infection in Australia. Med J Aust 2016;204:274.

Yohannes K, Dalton CB, Halliday L, Unicomb LE, Kirk M. An outbreak of gastrointestinal illness associated with the consumption of escolar fish. Commun Dis Intell Q Rep 2002;26: $441-445$.

Address correspondence to: Neil Franklin, BSc (Hons) NSW Ministry of Health Health Protection NSW Communicable Diseases Branch Level 7, 100 Christie Street, St. Leonards Sydney 2065 Australia

E-mail: neil.franklin@health.nsw.gov.au 